\title{
Meta
}

Journal des traducteurs

Translators' Journal

\section{VORDEROBERMEIER, Gisella M., ed. (2014): Remapping Habitus in Translation Studies. Amsterdam/New York: Rodopi, 235 p.}

\section{Anne-Marie Gagné}

Volume 64, numéro 1, avril 2019

URI : https://id.erudit.org/iderudit/1065338ar

DOI : https://doi.org/10.7202/1065338ar

Aller au sommaire du numéro

Éditeur(s)

Les Presses de l’Université de Montréal

ISSN

0026-0452 (imprimé)

1492-1421 (numérique)

Découvrir la revue

Citer ce compte rendu

Gagné, A.-M. (2019). Compte rendu de [Vorderobermeier, Gisella M., ed. (2014): Remapping Habitus in Translation Studies. Amsterdam/New York:

Rodopi, 235 p.] Meta, 64(1), 285-286. https://doi.org/10.7202/1065338ar

Ce document est protégé par la loi sur le droit d'auteur. L'utilisation des services d'Érudit (y compris la reproduction) est assujettie à sa politique d'utilisation que vous pouvez consulter en ligne.

https://apropos.erudit.org/fr/usagers/politique-dutilisation/
Cet article est diffusé et préservé par Érudit.

Érudit est un consortium interuniversitaire sans but lucratif composé de l'Université de Montréal, l'Université Laval et l'Université du Québec à Montréal. Il a pour mission la promotion et la valorisation de la recherche. https://www.erudit.org/fr/ 


\section{DOCUMENTATION}

\section{Comptes rendus}

Vorderobermeier, Gisella M., ed. (2014): Remapping Habitus in Translation Studies. Amsterdam/NewYork: Rodopi, 235 p.

Pierre Bourdieu's habitus has been a fundamental concept in the sociology of translation since the early 2000s. Almost fifteen years later, Remapping Habitus in Translation Studies is a successful attempt at reassessing its role in the examination of translation practices. The book, edited by Gisella M. Vorderobermeier (Assistant Professor in the Department of Translation Studies at KarlFranzens-Universität, Graz, Austria), stems from reflections presented at an international research symposium held in Graz in 2012, following on the international conference "Translating and Interpreting as a Social Practice"1 (2005). Collectively, the eleven contributions to this book address the relevance and uses of Bourdieu's habitus in Translation Studies from the twin perspectives of "what has been achieved to date and what challenges await us" (p. 15). They present an excellent coverage of the topic, embracing a broad range of methodological propositions, theoretical considerations, and critical examinations. Some of the papers presented in this volume follow the well-travelled path of using the habitus as a point of departure for considering individual trajectories while others introduce innovative readings of the concept and less conventional approaches.

Students in search of a detailed, yet concise, presentation of the habitus will be delighted to find that the Introduction provides a historical and general overview of the concept accompanied by a brief review of its application in translation studies. In these first pages, Vorderobermeier also positions, with clarity, the publication's project and objectives. The book is organised in four Parts which tackle, in turn, the theoretical dimension of the habitus, its intradisciplinary connections to other approaches, its methodological aspect, and critical perspectives on the concept. Each paper has its own bibliography-a more efficient arrangement than one lengthy combined bibliography, in our opinion-and there is an index of major themes at the end of the book.

The two contributions in Part I, General Theoretical Aspects, discuss very different dimensions of the concept. It opens with Jean-Marc Gouanvic contribution, "Is Habitus as Conceived by Pierre Bourdieu Soluble in Translation Studies?" In it, Gouanvic revisits some of his earlier findings on the habitus of two translators, Marcel Duhamel and Maurice-Edgar Coindreau (Gouanvic 2007). This opening paper relates translation practices to the field of a literary genre, the roman noir. In the second contribution, "Translators' Identity Work: Introducing Micro-Sociological Theory of Identity to the Discussion of Translators' Habitus," Rakefet Sela-Sheffy questions Bourdieu's lack of concern for identity components, including self-perception, and indicates their importance in understanding translators' professional choices (p. 52).

Part II, Intra-disciplinary Interrelations (Re) visited, comprises four papers. The first, "Remapping Habitus: Norms, Habitus and the Theorisation of Agency in Translation Practice and Translation Scholarship," by Sameh F. Hanna is remarkable for its direct engagement with the topic of the book. The author suggests four essential elements to be taken into account in (re)mapping habitus: its interdependence with other core Bourdieusian concepts, its relation to other underused Bourdieusian concepts, the empirical grounding of Bourdieu's theory, and the theory's historical dimension. Hanna also discusses, in the context of the translation of Shakespeare in Egypt, translatorial agency in dialogue with the concepts of habitus and norm. He proposes two concepts - doxa and hexis - as visible manifestations of the habitus. In the second paper, "Translatorial Hexis and Cultural Honour: Translating Captain Corelli's Mandolin into Greek," Kalliopi Pasmatzi also highlights the use of hexis as the translator's textual stance (p. 74) and points to its relevance in linking textual strategies to the wider social context. Nadja Grbićs "Interpreters in the Making: Habitus as a Conceptual Enhancement of Boundary Theory?" convincingly demonstrates the worthwhileness of complementing research on boundary work -a dynamic and anti-deterministic framework that focuses on the "generative power of interaction"with the habitus, which addresses the dimension of "underlying forces and enduring dispositions" (p. 100). Finally, Kristiina Abdallah also adopts a dual approach by combining the Latourian and Bourdieusian perspectives. In "The Interface between Bourdieu's Habitus and Latour's Agency: The Work Trajectories of Two Finnish Translators," she examines, in a longitudinal study, the trajectory of two translators, a path rarely pursued (unfortunately) in our discipline. 
In Part III, The Relationships Between Theory and Empirical Studies-Methodological Aspects, the focus is on three different methodological tools. Torikai Kumiko's “Oral History as a Research Method to Study Interpreters' Habitus” explores the use of life-story interviews to identify a translators' primary habitus, from the perspective of his lived experience. In "The (Re-)Construction of Habitus: A Survey-Based Account of Literary Translators' Trajectories Put into Methodological Perspective," Gisella M. Vorderobermeier presents the construction of a survey that attempts to reconstruct the literary translator's habitus by focusing on the temporal dimension, using Bourdieu's "differential anthropology of symbolic forms." Closing out this section of the book, Vasso Yannakopoulou uses the habitus to account for the internalisation of contextual factors that shape the observed results of translation choices. Her contribution "The Influence of the Habitus on Translatorial Style: Some Methodological Considerations Based on the Case of Yorgos Himonas' Rendering of Hamlet into Greek," together with Pasmatzi's contribution, indicates that textual analysis is not incompatible with sociological research, and that we might be on our way to escaping "the danger of a sociology of translation [...] without translation" (Wolf 2007: 27).

Finally, Part IV, Political and/or Critical Aspects of the Habitus Concept in Translation Studies, brings together two very different papers. Moira Inghilleri's contribution, "Bourdieu's Habitus and Dewey's Habits: Complementary Views of the Social?," draws a parallel between pragmatism's habit concept and the habitus. She concludes that while both concepts display striking similarities, Bourdieu's view disregards the role of language in social reproduction or change. She then applies both concepts to the analysis of a court interpreting case, accentuating active participation by the translator that departs from his duty to remain impartial. In "The Historian as Translator: Applying Pierre Bourdieu to the Translation of History," María Carmen África Vidal Claramonte makes use of the concepts of symbolic capital and habitus to explain from a historical perspective the selection of texts to be translated. She highlights the constructed nature of texts and proffers a vision of history as a translation of reality in a metaphorical sense, a process deeply shaped by the historian's ideological beliefs.

On the whole, Remapping Habitus in Translation Studies undoubtedly contributes to the "consolidation of the strong conceptual and methodological claims made by the sociology of translation" (p. 16) and demonstrates that the habitus is indeed a powerful concept for considering translation phenomena in relation to translators, their socio-professional situations, and their wider cultural and historical context. It also strikes a very engaging balance in presenting work from both young researchers and established specialists in the Bourdieusian approach. Yet the wide range of perspectives and applications presented, worthwhile and absorbing in themselves, do little to counteract the impression of "theoretical arbitrariness" (p. 15) one might get when comparing the wildly divergent views. Three questions remain unaddressed, in our view. First, is conceptualising a conscious habitus - one that the agent is aware of and can comment on (for example, in interviews) - a fruitful path? In other words, does a conscious habitus retain its function as an interface between collective and individual practices? Second, do self-perceptions, which undoubtedly reflect of the unconscious habitus of a translator, exert any influence in shaping it? Third, what significance is there in studying the habitus of individual translators without an accompanying examination of the specific habitus in terms of its relevant field of practice?

Still, in considering the habitus from very different standpoints, this publication engages in a lively inter- and intra-disciplinary dialogue that fosters a more thorough examination of the substantial contribution of the habitus to the sociology of translation. In sum, this volume might not have been conceived to settle a debate. Nor does it do so. Rather, it provides essential reading not only for the student desiring an overview of Bourdieu's habitus concept and its multiple applications in translation studies, but also for the scholar seeking out contemporary reflections on its theoretical and methodological implications.

AnNe-Marie Gagné Université de Montréal, Montreal, Canada

\section{NOTES}

1. International conference held at the KarlFranzens-Universität, Graz, Austria, on May 5-7, 2005.

\section{REFERENCES}

Gouanvic, Jean-Marc (2007): Pratique sociale de la traduction. Le roman réaliste américain dans le champ littéraire français (1920-1960). Arras: Artois Presses Université.

Wolf, Michaela (2007): Introduction: The Emergence of a Sociology of Translation. In: Michaela Wolf and Alexandra FuKari, eds. Constructing a Sociology of Translation. Amsterdam/Philadelphia: John Benjamins, $1-36$. 